\title{
VÙNG CỬA SÔNG Ở HẢI PHÒNG - TÀI NGUYÊN VI THÊ VÀ TIỀM NĂNG PHÁT TRIỂN
}

\author{
Trần Đức Thạnh ${ }^{1^{*}}$, Lê Đức An², Trịnh Minh Trang1 \\ ${ }^{1}$ Viện Tài nguyên và Môi trường biển-Viện Hàn lâm Khoa học và Công nghệ Việt Nam \\ ${ }^{2}$ Viện Địa lý-Viện Hàn lâm Khoa học và Công nghệ Việt Nam \\ "E-mail: thanhtd@imer.ac.vn
}

Ngày nhận bài: 21-1-2014

\begin{abstract}
TÓM TÄT: Các vùng cưa sông ở Hải Phòng (VCSHP) có tiềm năng lớn về tài nguyên vị thế đối với phát triển kinh tế - xã hội của thành phố. Về tài nguyên địa - tư nhiên, đây là vị trí đầu mối của các hệ thống thủy đạo sông - biển, vị trí chuyển tiếp giũa lục địa và biển, bản lề giữa ven bờ Đông Bằc và đồng bằng châu thổ sông Hồng, là cửa ngõ của Bắc Bộ và Nam Trung Quốc. Đó là các VCS hình phễu và châu thổ điển hình, có cấu trúc nưa kín, hệ thống luồng lạch sâu rộng, khá ổn định và có diện tích vùng triều rộng lớn. VCSHP có quá trình tiến hóa tự nhiên lâu dài, nằm ở ven biển nhiệt đới gió mùa có điều kiện tụ nhiên khá ổn định và thiên tai không quá khắc nghiệt. Đây còn là vùng có các tài nguyên thiên nhiên khác phong phú và đặc biệt chể độ nhật triều đều biên độ lớn mang lại nhiều lợi ích lớn về kinh tế và môi truờng. Về tài nguyên địa-kinh tế, VCSHP có giá trị là cưa mở huoơng biển ở ven bờ phía Bắc Việt Nam, có vai trò gắn kết Hải Phòng với thủ đô chinh trị Hà Nội. Đây là khu vưc trung tâm của không gian kinh kế vùng Duyên hải Bắc Bộ và là vị trí trung tâm của hệ thống kinh tế hai hành lang (Hải Phòng - Hà Nội - Nam Ninh và Hải PhòngHà Nội - Côn Minh) - một vành đai (vịnh Bắc Bộ) trong quá trình phát triển hội nhập quốc tế. Đặc biệt, VCSHP còn là địa bàn thuận lợi để uu tiên phát triển nhiều ngành kinh tế biển và khu kinh tế biến trọng điểm. Về tài nguyên địa - chính trị, VCSHP là không gian phát triển các khu dân cu và đô thị hóa ven biển, noi hội tụ nhiều yếu tố góp phần đảm bảo an ninh quốc phòng, hỗ trọ giũu vũng chủ quyền và lợi ích quốc gia trên biển. Đây cũng là noi phát triển và luu tồn nhiều giá trị văn hóa bản địa đặc sắc.
\end{abstract}

Tù khóa: Tài nguyên vị thế, vùng cửa sông, Hải Phòng.

\section{MỞ ĐÀ̀U}

Tài nguyên vị thế lần đầu được sử dụng để đánh giá tài nguyên quận Hồng Bàng, Hải Phòng [10] và sau đó đã được đề cập trong hệ thống tài nguyên biển Việt Nam [7]. Nhưng chỉ gần đây, tài nguyên vị thế biển, đảo và ven bờ Việt Nam mới được xây dựng thành hệ thống cơ sở lý luận [15, 19, 21, 23] và bước đầu đã được áp dụng mở rộng để nghiên cứu, đánh giá ở tầm vĩ mô $[3,6,27]$, cũng như ở một số trường hợp cụ thể $[1,2,18,25,29]$.
Tài nguyên vị thế là những lợi ích có được từ vị trí địa lý và các thuộc tính về cấu trúc, hình thể sơn văn và cảnh quan, sinh thái của một khu vực, có giá trị sử dụng cho các mục đích phát triển kinh tế-xã hội, đảm bảo an ninh, quốc phòng và chủ quyền quốc gia $[19,27]$. Nhóm tài nguyên này được chia thành ba hợp phần: địa-tự nhiên, địa-kinh tế và địa-chính trị và sự kết hợp giữa chúng tạo nên giá trị tổng hợp cho phát triển kinh tế-xã hội của một lãnh thổ $[25,29]$. Hải Phòng là địa phương cấp tỉnh duy nhất ở Việt Nam có cả vùng cửa sông hình 
phễu và châu thổ. Bài viết này trình bày kết quả nghiên cứu về tài nguyên vị thế các vùng cửa sông ở Hải Phòng (VCSHP), một dạng tài nguyên có tầm quan trọng đặc biệt đối với quy hoạch không gian biển phục vụ phát triển kinh tế - xã hội của thành phố [26].

\section{TÀI LIỆU VÀ SỐ LIỆU SỬ DỤNG}

Bài báo này được hoàn thành chủ yếu dựa vào kết quả điều tra của dự án 14 "Điều tra co bản và đánh giá tài nguyên vị thế, kỳ quan sinh thái, địa chất vùng biển và các đảo Việt Nam" thuộc Đề án tổng thể 47 "Điều tra cơ bản và quản lý tài nguyên môi trường biển đến năm 2010, tầm nhìn đến năm 2020" do Viện tài nguyên và Môi trường biển chủ trì, được thực hiện trong các năm 2008 - 2011.

Ngoài ra, bài báo còn sử dụng các kết quả điều tra, nghiên cứu về điều kiện tự nhiên, tài nguyên thiên nhiên và môi trường đã được công bô hoặc lưu trữ tại Viện Tài nguyên và Môi trường biển, Viện Nghiên cứu Hải sản, Cục Địa chất Việt Nam, Đài Khí tượng Thủy văn Đông Bắc và nhiều cơ quan khác. Các tài liệu về kinh tế - xã hội được tham khảo từ các cơ quan quản lý tại Hải Phòng, đáng lưu ý nhất là công trình: "Quy hoạch xây dựng vùng Duyên hải Bắc Bộ đến năm 2025 và tầm nhìn đến năm 2050", hoàn thành năm 2008 và được lưu trữ tại Viện Quy hoạch thành phố Hải Phòng.

\section{GIÁ TRI TÀI NGUYÊN ĐỊA - TỰ NHIÊN}

Vị trí không gian các vùng cửa sông Hải Phòng

Vị trí đầu mối của các hệ thống thủy đạo sông - biển

Sông lạch Hải Phòng dày đặc, thuộc về hệ thống sông Thái Bình và sông Hồng kết nối và giao hòa với nhau qua các nhánh, rồi đổ ra biển theo năm cửa (river mouths) chính: Lạch Huyện, Nam Triệu, Cấm, Lạch Tray, Văn Úc và Thái $B i ̀ n h . ~ B a$ cửa đầu thuộc vùng cửa sông (VCS) hình phễu (estuary) [9], Bạch Đằng và hai cửa sau thuộc VCS Văn Úc, thuộc châu thổ (delta) sông Hồng hiện đại. Qua các cửa, tàu thuyền từ biển, bằng các cách khác nhau đều có thể ngược dòng lên Hà Nội và xa hơn nữa về phía thượng du Bắc Bộ.
Các sông Lục Nam, Thương, Cầu và Đuống thuộc hệ thống sông Thái Bình sau khi hợp lưu ở gần Phả Lại đã phân thành hai nhánh chính là Kinh Thầy và Thái Bình. Gần sát biển, chúng hợp lưu và rồi lại phân lưu thành sông Chanh đồ ra cửa Lạch Huyện, sông Bạch Đằng đổ ra cửa Nam Triệu, sông Cấm và Lạch Tray đổ ra cửa Ba Lạch [28]. Từ năm 1981, do đắp đập Đình Vũ, nước sông Cấm dồn cả ra cửa Nam Triệu. Ngoài ra, còn có một số nhánh nối ngang như Tam $B a ̣ c$ nối sông Cấm và Lạch Tray, Ruột Lợn nối sông Cấm với Bạch Đằng. Nhánh Tam Bạc nằm áp thế đất cao nên đã thành một thương bến giàu có vào đầu thế kỷ XX.

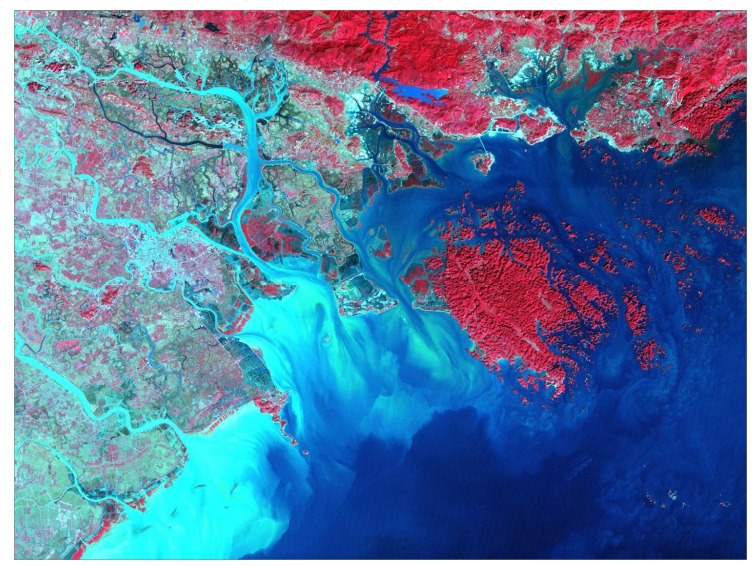

Hình 1. Vùng cửa sông ven biển Hải Phòng nhìn từ ảnh vệ tinh Spot

Ở phía Tây Nam Đồ Sơn, sông Văn Úc kết nối với nhánh sông Luộc rồi đổ ra biển qua hai cửa Văn Úc và Thái Bình. Sông Mới đào năm 1936 nối tuyến từ biển vào sông Văn Úc, sang sông Luộc, sông Nam Định rồi ngược lên Hà Nội. Vào thời Kẻ Chợ, sông này vẫn còn là một nhánh tự nhiên, thương thuyền ngược dòng Thái Bình, qua một nhánh ngang nay đã tàn để cập bến đô thị Domea, rồi vào sông Mới, sang sông Luộc và lên Thăng Long.

Vị trí chuyển tiếp giũa đồng bằng luc địa và biển

Đồng bằng châu thổ và một phần là thềm biển cổ, chiếm $85 \%$ diện tích tự nhiên, bề mặt phân bậc độ cao trong khoảng 0,5-4 m, bị chia cắt bởi sông lạch, ao hồ khá dày đặc. Trên mặt đồng bằng, các đê cát cổ cao 2-2,5 m đến 5 - 
6 m, tạo thành các dải song song bờ biển. Đồi và núi thấp chiếm khoảng $5 \%$ diện tích, chủ yếu ở Bắc Thuỷ Nguyên và dải Kiến $\mathrm{An}$ - Xuân Sơn, cao phổ biến 40-100 m, cao nhất $200 \mathrm{~m}$. Đồi núi Đồ Sơn nhô ra biển thành bán đảo dài $7 \mathrm{~km}$, cao nhất $125 \mathrm{~m}$. Vùng nước đến độ sâu khoảng 5-6 $\mathrm{m}$ và vùng biển ven bờ đến độ sâu $30 \mathrm{~m}$ nông thoải và trải rộng, có tác dụng giảm sóng biển nên làm cho VCS an toàn hơn.

Các VCSHP nằm kề cận và đan xen với đồng bằng có những phần nồi cao và một diện tích đáng kể đồi núi, thoát khỏi ảnh hưởng ngập lụt của thủy triều và mưa lũ để hình thành các khu dân cư và đô thị, các khu kinh tế và xây dựng cơ sở hạ tầng. Tương tác vật chất và động lực tại các VCS mạnh mẽ và tích cực, tạo một không gian động chuyển tiếp giữa biển và đẩt liền, giàu dinh dưỡng, đa dạng sinh cảnh sống, biên độ mặn rộng và đa dạng sinh học cao, phong phú nguôn lợi thủy sản ít nơi nào sánh được; đồng thời tạo ra một số khu vực đất bồi, hàng năm mở lấn đáng kể ra phía biển.

Vị trí bản lề giữa ven bờ Đông Bắc và đồng bằng Bắc Bộ trên dải bờ Tây vịnh Bắc Bộ

VCSHP nằm ở vùng chuyển tiếp giữa hai cấu trúc địa chất lớn là đai tạo núi nội lục Paleozoi sớm thuộc hệ tạo núi đa kỳ Neoproterozoi - Mezosoi sớm và trũng châu thổ sông Hồng thuộc các trũng nội lục Paleozoi muộn - Kainozoi qua đới nâng Kiến An - Đồ Sơn [31]. Bán đảo Đồ Sơn là ranh giới giữa hai VCS hình phễu và VCS châu thổ. VCS hình phễu Bạch Đằng là nơi biển lấn hiện đại; ven bờ là cảnh quan đồng bằng đa dạng với nhiều kênh lạch và ao hồ xen kẽ gò đồi; có điều kiện sinh thái nước mặn lợ, đa dạng sinh học cao, đa dạng kiểu loại đất và ảnh hưởng của thuỷ triều trên sông rất mạnh [13]. VCS châu thổ Văn Úc có đồng bằng ven biển thoải, ít bị chia cắt phức tạp, vắng mặt đồi núi và đất phù sa màu mỡ cho phát triển nông nghiệp; có điều kiện sinh thái nước lợ và nguồn lợi thủy sản phong phú.

Dải bờ Tây vịnh Bắc Bộ (VBB) được chia thành 4 vùng tự nhiên: 1 . Móng Cái-Đồ Sơn; 2. Đồ Sơn-Lạch Trường; 3. Lạch Trường-Mũi Roòn; và 4. Mũi Roòn- Hải Vân. VCSHP nằm trên vị trí bản lề của dải ven bờ Bắc Bộ, chuyển tiếp giữa vùng 1 (ven bờ Đông $B a ̆ ́ c)$ và vùng 2 (ven bờ châu thổ sông Hồng hiện đại) [24].
VCSHP nằm ở khoảng giữa bờ VBB tự nhiên, tính từ cực Nam đảo Hải Nam (Trung Quốc) tới mũi Hải Vân (Việt Nam).

\section{Quốc}

Vị trí cửa ngõ của Bắc Bộ và Nam Trung

Đây là giá trị nổi bật của vị thế VCSHP so với toàn bộ các VCS của Bắc Bộ và Bắc Trung Bộ. Người Pháp đã sớm nhận ra ưu thế này khi quyết định xây dựng cảng Hải Phòng và làm đường sắt Hải Phòng-Hà Nội-Côn Minh. Mặc dù các cửa Đáy, Ba Lạt vẫn có thể được sử dụng cho giao thông thủy, nhưng phải chỉ có VCSHP, với VCS Bạch Đằng cấu trúc hình phễu là cửa thuận lợi, an toàn và ổn định nhất cho Bắc Bộ và thủ đô Hà Nội liên hệ với hải ngoại, thông qua các tuyến sông-biển, hải cảng và các tuyến hàng hải quốc tế, được hỗ trợ bởi các tuyến đường sắt và đường bộ cao tốc vào sâu trong lục địa. Vị trí cửa ngõ của VCS Bạch Đằng đã và sẽ mang lại lợi ích to lớn về cả địakinh tế và cả địa-chính trị, địa-quân sự.

\section{Hình thể và cấu trúc không gian các vùng cửa sông}

Các VCS hình phễu và châu thổ điển hình quy mô quốc gia và khu vục

Trong số 114 cửa sông của Việt Nam, Hải Phòng có 5 cửa $(4,4 \%)$, chiếm $3,4 \%$ khối lượng nước đổ ra biển $\left(30 / 880\right.$ tỷ $\mathrm{m}^{3}$ mỗi năm) và $7,2 \%$ khối lượng phù sa $(18 / 250$ triệu tấn mỗi năm) [8]. Các cửa sông của Hải Phòng đều thuộc loại rộng, sâu và lượng chảy triều đóng vai trò lớn trong tổng lượng dòng ở vùng cửa. Các VCSHP thuộc về hai kiểu châu thổ và hình phễu, khác nhau về cấu trúc, nguồn gốc, tiến hóa tự nhiên, các quá trình động lực, tài nguyên nói chung và tài nguyên vị thế nói riêng.

VCS hình phễu Bạch Đằng $[11,16]$ có quy mô lớn thứ hai ở Việt Nam, chỉ sau VCS hình phễu Đồng Nai $[16,32]$. Nó được hình thành trên cơ sở tương tác giữa quá trình phát triển của một địa hào kiến tạo hiện đại đang sụt chìm [4] với sự nâng cao của mực nước chân tĩnh, sự thiếu hụt bồi tích và thuỷ triều có biên độ lớn [13]. Đây là trường hợp điển hình về một VCS hình phễu phát triển trong điều kiện nhật triều biên độ lớn. Hầu hết các cảng biển lớn nhất của thế giới, trong đó có Rotterdamcảng của Châu Âu, nằm ở VCS hình phễu. Hai 
cảng biển lớn nhất Việt Nam là Sài Gòn và Hải

là Đồng Nai và Bạch Đằng, nằm giáp kề phía Phòng đều nằm ở các vùng cửa sông hình phễu

Bắc hai châu thổ Mê Kông và sông Hồng.

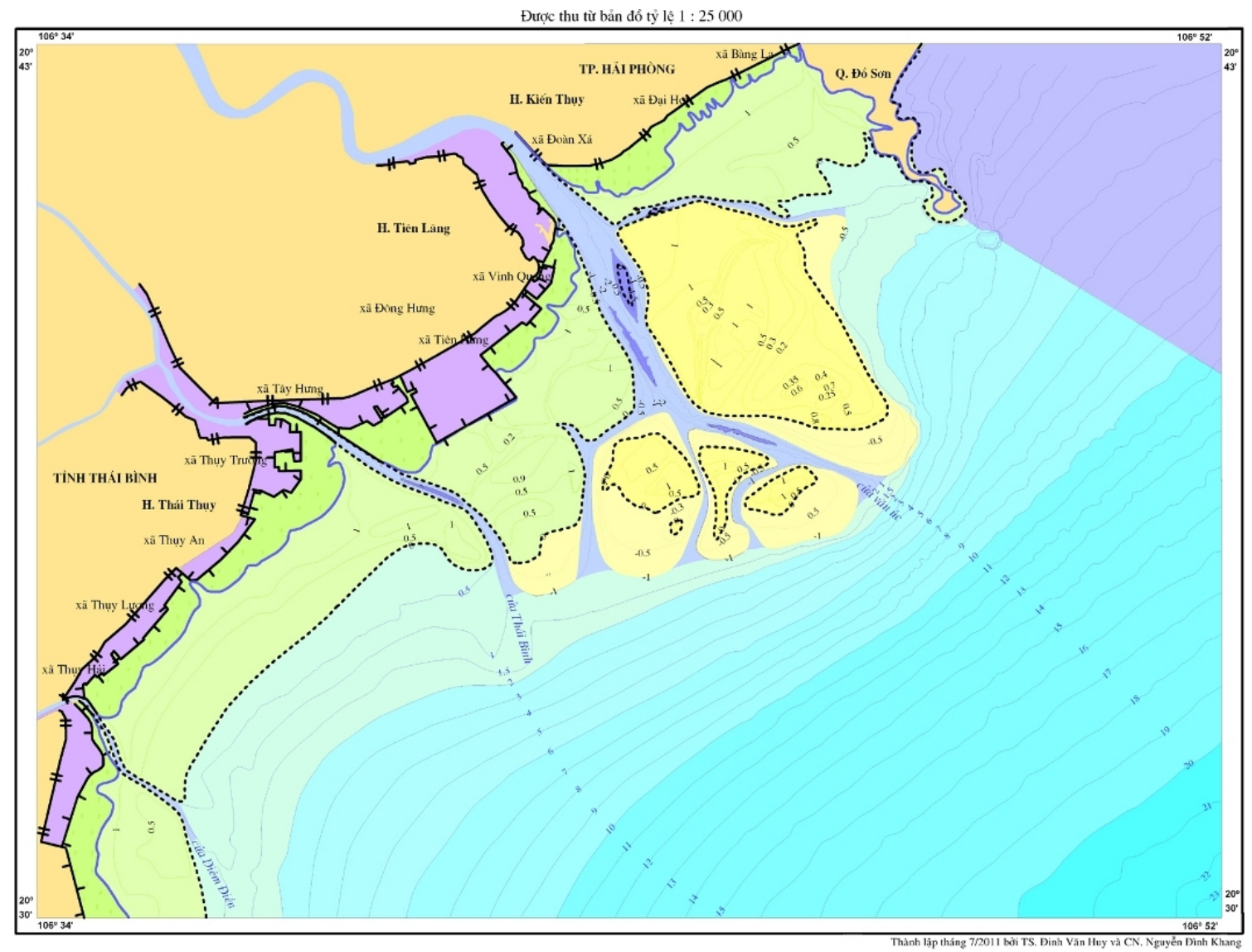

Hình 2. Hình thái địa hình vùng cửa sông Văn Úc

[Nguồn: Nguyễn Đúc Cự và nnk, 2011. Báo cáo đánh giá tác động thủy thạch động lự phục vu lập dự án tuyến đê quai lấn biển huyện Tiên Lãng]

VCS Văn Úc kiểu châu thổ điển hình (hình 2), nơi động lực sông đóng vai trò quyết định, hình thái cửa sông có phần đơn giản hơn, bờ biển ít bị chia cắt phức tạp bởi các lạch triều, hình thái bờ có dáng lồi ra phía biển. Các bãi bồi ngập triều cơ bản được bồi tụ nổi cao và mở lấn ra phía biển hàng chục mét mỗi năm. Các bãi triêu cao có sú vẹt hẹp, trong khi các bãi triều thấp trải rộng tới $5-6 \mathrm{~km}$. Cửa các nhánh sông đổi hướng nhanh và phức tạp. Sông Hồng có vị trí thứ năm ở các châu thổ Đông A (sau Hoàng Hà, Trường Giang, Mê Kông và Amur) và vị trí 14 trên thế giới. Trong số 9 cửa của hệ thống Sông Hồng, Hải Phòng có 2 cửa và Văn Úc là một trong ba cửa lớn nhất cùng với cửa $\mathrm{Ba}$ Lạt và cửa Đáy.

\section{Cấu trúc nưa kín}

Các thủy vực ven bờ cấu trúc nửa kín có giá trị đối với để neo trú tự nhiên cho tầu thuyền tránh bão gió [20], xây dựng cơ sở hạ tầng, cảng biển, phát triển dân sinh và kinh tế bền vững và hạn chế các tai biến từ biển. Nếu thủy vực quá kín, dễ sinh ô nhiễm và ngập lụt khi có mưa lũ lớn như ở miền Trung. VCS Bạch Đằng có cấu trúc nửa kín điển hình do đường bờ lõm và sự phân cách tương đối với biển nhờ quần đảo Cát Bà che chắn ở phía Đông, Đông Nam và bán đảo Đồ Sơn ở phía Tây, nên chỉ sóng hướng Nam và Đông Nam mới có khả năng lan truyền từ biển vào với độ cao thường không quá $3 \mathrm{~m}$. Nhờ đó, tác động của sóng, bão đối với VCS này được hạn chế 
đáng kể [17]. VCS Văn Úc nằm ở vùng châu thổ nhưng có kích thước lớn và độ sâu đáng kể, lối vào từ biển thông thoáng hơn cả cửa $\mathrm{Ba}$ Lạt và Cửa Đáy. Cửa này cũng có xu hướng hình phễu hóa, tạo không gian mặt nước cho hành thủy, neo đậu và thoát lũ. Bán đảo Đồ Sơn có tác dụng làm giảm ảnh hưởng của động lực biển tới VCS Văn Úc vào mùa gió ĐB. dịnh

Hệ thống luồng lạch sâu rộng và khá ổn

Luồng lạch sâu và ổn định là yếu tố vô cùng quan trọng để thoát lũ, phát triển cảng bến và khu neo đậu cho tàu thuyền [20]. VCS Bạch Đằng có một hệ thống luồng lạch khá ổn định, rộng đến trên $1 \mathrm{~km}$ và sâu đến 10-15 m. Các bản đồ thời Pháp cho thấy độ sâu luồng 15-20 m rất phổ biến, nay giảm đi rất nhiều do sa bồi. Dọc ven luồng ngoài cửa có các doi cát (chương cát), kéo dài hàng $\mathrm{km}$, thường nổi cao trên mực triều trung bình. Phía Tây Lạch Huyện có chương Hàng Dày, phía Đông luồng Nam Triệu có chương Hoàng Châu và phía Tây luồng này có chương Đình Vũ (hình 3). Đó là các dạng tích tụ tạo nên do dòng triều rút ở vùng động lực triều thống trị, khác hẳn các doi cát dọc bờ phát triển lấn ngang luồng cửa sông ở các vùng sóng mạnh miền Trung, hay các cồn bãi chắn cửa sông châu thổ (cửa Ba Lạt, cửa Đáy).

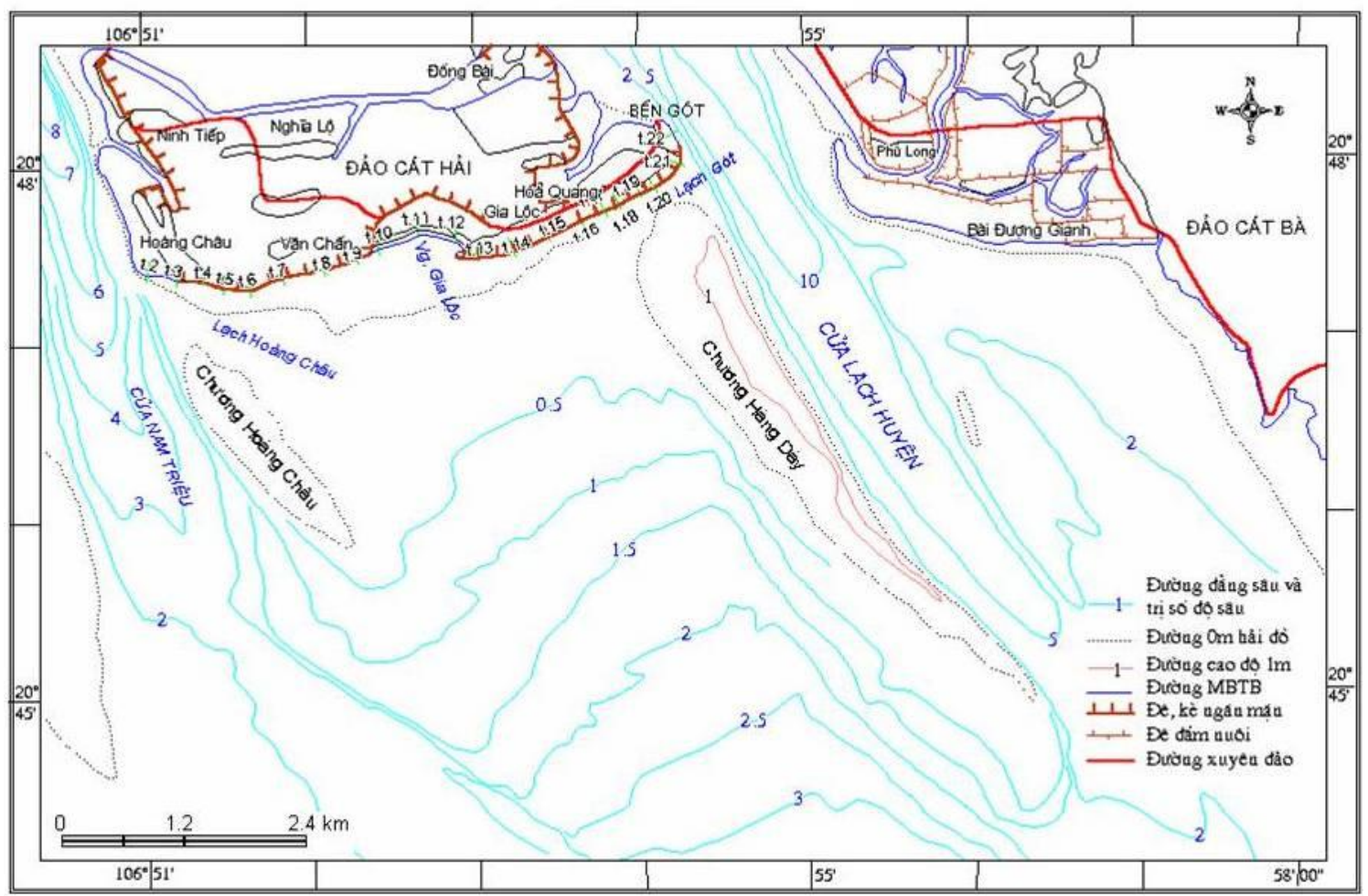

Hình 3. Luồng cửa Nam Triệu, Lạch Huyện và các doi cát triều

Hai luồng Nam Triệu và Lạch Huyện co bản có đặc điểm hình thái-động lực tương đồng. Nếu sử dụng luồng cho tầu cỡ $3-5$ vạn tấn ra vào thì phải chỉnh trị bằng kè dọc luồng vươn xa ra biển đến độ sâu 13-15 m, thì luồng Lạch Huyện không có ưu thế gì hơn luồng Nam Triệu, nhưng chi phí lớn hơn vì phải qua kênh đào Hà Nam và gây tác động môi trường xấu hơn đối với Di sản thế giới vịnh Hạ Long và khu Dự trữ sinh quyển thế giới quần đảo Cát Bà.

Luồng phía trong cửa Văn Úc khá ổn định, nhưng phía ngoài cửa thường bị các bãi ngầm bồi lấn. Tuy nhiên, việc chỉnh trị tạo luồng cho tàu biển trọng tải lớn vào sâu trong sông là có thể nếu xây dựng kè dọc luồng hai phía vươn 
đến độ sâu cần thiết vượt khỏi tác động của dòng bồi tích di chuyển dọc bờ gây sa bồi.

\section{Vùng triều cưa sông rộng lớn}

Vùng triều VCSHP có diện tích khá lớn và là một hệ thống bao gồm các bãi lầy sú vẹt, các bãi triều thấp và hạn chế hơn là các bãi cát biển và bãi triểu rạn đá [12]. Ở VCS Bạch Đằng, về cơ bản vùng triều không được bồi tụ mở rộng, thậm chí còn bị xói lở thu hẹp do biển lấn và dâng cao mực biển. Tuy nhiên, những bãi triều rộng lớn đã được bồi tụ từ hàng ngàn năm trước rất có giá trị đối với nuôi trồng thủy sản mặn lợ, xây dựng các khu kinh tế lớn, các bến cảng, các khu dịch vụ đi kèm và các khu đô thị mới. Ở VCS Văn Úc, vùng triều có $x u$ hướng bồi tụ mở rộng ra phía biển. Bãi bồi Tiên Lãng nằm giữa hai cửa Văn Úc và Thái Bình có thể quy hoạch diện tích đến 5.600 ha để xây dựng một sân bay quốc tế lớn.

\section{Động lực và tính ổn định của các vùng cửa sông}

VCSHP có một lịch sủ hình thành và tiến hóa tư nhiên lâu dài, có những khu đất cổ nổi cao từ hàng chục triệu năm, có những vùng đất phù sa trẻ đang hàng ngày bồi lấn ra biển. Khoảng 1.000 - 700 năm trước, VCS Bạch Đằng bồi tụ kiểu châu thổ. Đến 700-500 năm trước, quá trình bồi tụ lấn biển đã nối đồng bằng Kiến Thụy với đảo Đồ Sơn thành bán đảo và tạo thành một kè tự nhiên chắn bùn cát nguồn gốc sông Hồng dọc bờ từ phía Tây Nam đi lên. Từ đó, VCS Bạch Đằng thiếu hụt bồi tích và chuyển thành cấu trúc hình phễu. Từ ngàn năm trước đường bờ đã nằm phía ngoài đảo Cát Hải và trên 5 trăm năm trước, bờ biển VCS Bạch Đằng mở rộng hơn nhiều ra phía biển [14].

VCSHP nằm ở ven biển vùng nhiệt đới gió mùa có điều kiện tư nhiên và thiên tai không quá khắc nghiệt. Mùa hè nóng ấm trùng vào mùa gió Tây Nam với các hướng thịnh hành Đông và Đông Nam, thường có bão và áp thấp nhiệt đới. Mùa Đông trùng vào mùa gió Đông Bắc và ít mưa. Hàng năm có $1.600-1.900$ giờ nắng, lượng mưa loại trung bình ở nước ta, khoảng $1.500-1.800 \mathrm{~mm} / \mathrm{năm}$. Nước dâng trong bão gây nguy hiểm, nhất là khi trùng kỳ triều cường $(50 \%$ số cơn bão gây nước dâng từ $100 \mathrm{~cm}$ trở lên, $30 \%$ từ $150 \mathrm{~cm}$ trở lên và $11 \%$ trên $200 \mathrm{~cm}$ ). Biểu hiện đia chấn khá rõ với các chấn tâm động đất phân bố trên các đứt gãy, có thể đạt cường độ 5,6-6,5 độ Richter, chấn cấp Io $=8$ (thang MSK - 64) [4]. Dù vậy, so với nhiều vùng ven bờ khác ở Việt Nam và thế giới, khu vực có khí hậu và thời tiết khá thuận lợi, thuộc loại "mưa thuận, gió hoà" và ít rủi ro, thuận lợi cho phát triển bền vững.

VCSHP nằm ở vùng thủy triều, nhật triều đều biên độ lớn điển hình, với hầu hết số ngày trong tháng là nhật triều [30]. Độ lớn thuỷ triều thuộc loại lớn nhất nước ta, ở Hòn Dấu trung bình $3,0 \mathrm{~m}$, cực đại $4,18 \mathrm{~m}$, cực tiểu $1,75 \mathrm{~m}$. Trong một tháng mặt trăng có hai kỳ nước cường, mỗi kỳ 11-13 ngày và hai kỳ nước kém xen kẽ. Tốc độ dòng triều trung bình 20$50 \mathrm{~cm} / \mathrm{s}$, cực đại $150-180 \mathrm{~cm} / \mathrm{s}$, tương quan thời gian triều chảy lên và xuống 11-12 h/13-14 h [13]. Thủy triều nhật triều đều biên độ lớn và dòng chảy triều mạnh mang lại nhiều lợi ích lớn như hạn chế sa bồi, làm giảm khả năng kéo dài ngập lụt ven bờ, tự làm sạch môi trường tốt, thuận lợi cho các hải trình ra vào cảng, tạo nguồn năng lượng sạch cho tương lai ...

\section{Tài nguyên thiên nhiên đi kèm}

VCSHP giàu có tài nguyên phi sinh vật (nước, đất ngập nước, khoáng sản, năng lượng) và tài nguyên sinh vật (đa dạng sinh học, nguồn lợi thủy sản đánh bắt và nuôi trồng) và tài nguyên nhân văn [22]. Hàng năm các VCSHP nhận khoảng trên $30 \mathrm{~km}^{3}$ nước và khoảng 18 triệu tấn bùn cát từ lục địa, trong đó VCS Bạch Đằng nhận khoảng $14 \mathrm{~km}^{3}$ nước và 5 triệu tấn bùn cát. Hải Phòng có diện tích đất ngập nước ven bờ, chủ yếu đất ngập nước VCS, khoảng 65 nghìn ha $-42,8 \%$ diện tích đất tự nhiên thành phố, trong đó có 27 nghìn ha đất ngập triều, 38 nghìn ha đất dưới triều tính đến độ sâu $6 \mathrm{~m}$. Đây là vùng tiềm năng nuôi trồng thuỷ sản, giao thông và xây dựng cơ sở hạ tầng. Tài nguyên khoáng sản phong phú về vật liệu xây dựng, đặc biệt là nguồn đá vôi (trữ lượng 185 triệu tấn, tập trung ở Tràng Kênh) và nguồn cát xây dựng ở lòng sông và cửa sông. VCSHP có đa dạng sinh học rất cao, có nhiều tiểu hệ sinh thái với trên 1.200 loài. VCS có quan hệ với ngư trường cá đáy và cá nổi Cát Bà - Long Châu và các bãi tôm kéo dài từ Cát Bà đến cửa Thái Bình. 


\section{GIÁ TRI TÀI NGUYÊN ĐỊA-KINH TẾ}

Cửa mở hướng biển ở ven bò̀ phía Bắc và vai trò gắn kết Hải Phòng với thủ đô Hà Nội

Nhiều trung tâm kinh tế và đô thị lớn ở thế giới và Việt Nam gắn với các VCS (Hải Phòng, thành phố Hồ Chí Minh) hoặc vịnh biển (Đà Nẵng, Hạ Long). VCS Bạch Đằng có vai trò chủ đạo của cửa mở hướng biển để trở thành một trung tâm kinh tế lớn ở ven biển phía Bắc vì đã hội tụ được một số yếu tố cơ bản. Thứ nhất là các giá trị về tài nguyên địa-tự nhiên đảm bảo sự phát triển nội tại và phát triển liên kết, hòa nhập trong nước và khu vực nhờ giao lưu kinh tế mà giao thông cảng biển-hàng hải là đầu mối, sau đó là giao thông nội thủy và đường bộ, đường sắt và hàng không. Thứ hai, được đảm bảo về mặt an ninh quốc phòng để tránh những biến cố bất thường. Thứ ba, không xa và có vị trí trung tâm trong mối quan hệ với các đầu mối kinh tể khác.

Cửa mở hướng biển VCSHP đủ tiềm năng phát triển thành một trung tâm kinh tế hỗ trợ cho trung tâm chính trị - là thủ đô Hà Nội. Đó cũng là một kiểu mô hình quan hệ không gian của trung tâm kinh tế và trung tâm chính trị, ví dụ như Bắc Kinh và Thượng Hải, hay Washington và New York.

Cửa mở hướng biển liên quan đến vai trò của của cụm cảng Hải Phòng mà tâm điểm cảng nước sâu Lạch Huyện đang được xây dựng. Không nên xây dựng cảng Nam Đồ Sơn vì đây thuộc VCS châu thổ sa bồi mạnh, thiếu khả năng kết nối giao thông nội thuỷ, quá gần cảng nước sâu Lạch Huyện, đồng thời mâu thuẫn lợi ích với phát triến du lịch sinh thái nghỉ dưỡng tại bán đảo Đồ Sơn.

\section{Khu vực trung tâm của không gian kinh kế vùng duyên hải Bắc Bộ}

Hải Phòng là trung tâm kinh tế lớn thứ 3 cả nước, có hệ thống cảng biển gắn với hệ thống giao thông đồng bộ cả về đường sắt, đường bộ, đường sông, đường biển và hàng không; có các ngành công nghiệp quy mô lớn của cả nước (cơ khí đóng tàu, công nghiệp chế biến, công nghiệp sản xuất hàng tiêu dùng, sản xuất vật liệu xây dựng, dịch vụ cảng và vận tải biển ...); đồng thời là trung tâm thương mại, du lịch, dịch vụ lớn của vùng Bắc Bộ và cả nước ... đang có sức hút đầu tư quốc tế. Các lợi ích này có được là nhờ $\mathrm{VCS}$, đồng thời làm tăng giá trị sử dụng không gian VCS.

Vùng duyên hải Bắc Bộ, từ Quảng Ninh đến Ninh Bình, gồm 5 tỉnh và thành phố trực thuộc trung ương, có mật đô dân số cao nhất và có vai trò quan trọng đặc biệt đối với phát triển kinh tế - xã hội của đất nước. VCSHP, đặc biệt là VCS Bạch Đằng (kể cả phần tả ngạn thuộc Quảng Ninh) thực sự có tiềm năng phát triển kinh tế với tư cách trở thành trung tâm phát triển vùng với các điểm nhấn: 1 . Trung tâm về mặt khoảng cách địa lí so với cực Đông Bắc, Tây Nam vùng và khoảng cách tới thủ đô Hà Nội; 2. Là vị trí cửa mở hướng biển của cả nước ở phía Bắc với cảng nước sâu Lạch Huyện; 3. Nằm trên tuyến đường cao tốc dọc ven biển và là điểm nút nối tuyên với đường cao tốc Hà Nội - Hải Phòng; 4. Có khu kinh tế trọng điểm Đình Vũ - Cát Hải (21.640 ha), một trong $5 \mathrm{khu}$ kinh tế ven biển trọng điểm hàng đầu của cả nước; 5. Có tiềm năng phát triển sân bay quốc tế Tiên Lãng nằm sát đường cao tốc ven biển, một cửa khẩu hàng không quan trọng bậc nhất ở ven biển Bắc Bộ.

Đường cao tốc dọc ven biển theo quy hoạch sẽ kết nối VCS Bạch Đằng và Văn Úc, kết nối với các khu kinh tế trọng điểm như khu công nghiệp Hải Hà, khu kinh tế Vân Đồn, trung tâm kinh tế Hạ Long, Khu công nghiệp - dịch vụ đầm Nhà Mạc, khu kinh tế Đình Vũ - Cát Hải và nối tuyến với các khu kinh tế Bắc Trung Bộ.

VCSHP nằm cách đường hàng hải quốc tế hơn 50 hải lý, với bờ biển dài và 5 cửa lớn, nên trở thành cửa ngõ quan trọng liên thông các tuyến đường biền và đường sông. Từ đây có tuyến đường biển nối Hải Phòng với các nút ven biển khác trong nước (đi Cẩm Phả $90 \mathrm{~km}$; Móng Cái 196 km; Nam Định 153 km). Hệ thống đường sông hỗ trợ cho đường biển, đã tạo ra các luồng vận tải nội thủy, có thể cho phép tàu pha sông - biển vào sâu trong đất liền: tới Hà Nội 198 km; tới Việt Trì 300 km; tới Bắc Giang - Thái Nguyên 217 km.

\section{Vị trí trung tâm của hệ thống hai hành lang - một vành đai}

VCS Bạch Đằng là nơi nối tuyến giữa hai hành lang Hải Phòng - Nam Ninh và Hải Phòng - Côn Minh và vành đai kinh tế vịnh Bắc Bộ, ra 
đời trong bối cảnh toàn cầu hóa và quan hệ quốc tế đa phương, quan hệ song phương Việt Nam-Trung Quốc ngày càng phát triển. Không gian hợp tác gồm 4 tỉnh của Trung Quốc là Vân Nam, Quảng Tây, Quảng Đông, Hải Nam và 5 tỉnh, thành của Việt Nam là Lào Cai, Lang Sơn, Hà Nội, Hải Phòng và Quảng Ninh với tổng diện tích 869 ngàn $\mathrm{km}^{2}$ và dân số 184 triệu người. Các lĩnh vực hợp tác bao gồm thương mại, công nghiệp, nông nghiệp, du lịch, khai thác tài nguyên, chế biển và điện lực ... trong khuôn khô khu vực mậu dịch tự do Trung Quốc - ASEAN và hợp tác tiểu vùng sông Mê Kông [24].

Hợp tác hai hành lang và Một vành đai không chỉ có tầm ảnh hưởng đến hầu hết các tỉnh Đồng bằng Bắc Bộ mà còn liên quan đến các nước trong khu vực, vì Trung Quốc xem vịnh Bắc Bộ là cửa ngõ ra biển của miền Tây Trung Quốc thông qua hợp tác với Việt Nam và ASEAN trong khu vực mậu dịch tự do Trung Quốc-ASEAN [33], để tận dụng hệ thống cảng biển, tập trung ở Hải Phòng và Quảng Ninh trong mối liên kết với các cảng thuộc Quảng Tây, mà cảng Phòng Thành là chủ đạo.

Trên vành đai, Quảng Ninh và Hải Phòng đang phát triển trục giao thông nòng cốt ven biển Móng Cái-Hạ Long-Hải Phòng-Ninh Bình và các vùng động lực của duyên hải Bắc $B$ ộ. Nối với vành đai có các tuyến kinh tế trọng điểm vịnh Bắc Bộ: tuyến kinh tế đường 47 mở ra cảng Nghi Sơn; tuyến kinh tế đường 8 mở ra biển ở Cửa Lò và Vũng Áng; tuyến kinh tế đường 12 mở ra cảng Vũng Áng và Hòn $\mathrm{La}$; về phía Nam có tuyến kinh tế dọc đường 9 nối với hành lang Đông-Tây mở qua các cảng Chân Mây và Đà Nẵng [24]. Trên vành đai này, sân bay quốc tế Tiên Lãng trở thành cảng hàng không quan trọng nhất ven bờ Bắc Bộ.

\section{Địa bàn thuận lợi và ưu tiên phát triển nhiều loại hình kinh tế biển và khu kinh tế biển trọng điểm}

Trong nền kinh tế thị trường, dịch vụ biển là thế mạnh phát triển lớn nhất tại VCSHP với nhiều nhiều lĩnh vực ở quy mô khác nhau [26].

Dịch vụ cảng và hàng hải có tiềm năng lớn nhất và cấp thiết nhất. Kèm cảng là các dịch vụ hàng hải logistic, thương mại, ngân hàng và viễn thông ... phục vụ cho hàng hải và các lĩnh vực kinh tế biển khác. Dịch vụ hậu cần nghề cá có tiềm năng lớn và là nhu cầu cấp thiết phục vụ đánh bắt xa bờ kết hợp với thực thi chủ quyền trên vịnh Bắc Bộ, phát triển dịch vụ chế biến và phân phối sản phẩm thủy sản. Dịch vụ dầu khí được dự báo có nhiều tiềm năng trong tương lai gần và mang lại lợi ích đáng kể khi khai thác dầu khí trở thành khả thi trên vịnh Bắc Bộ. Dịch vụ du lịch (sinh thái, văn hóa) và nghỉ dưỡng sẽ trở thành một điểm hấp dẫn trong hệ thông du lịch biển Việt Nam. Do vị trí thuận lợi VCS sẽ là điểm đến của nhiều tàu du lịch lữ hành, nếu được tổ chức tốt. Dịch vụ tìm kiếm cứu nạn thực hiện các hoạt động cứu hộ, cứu nan, thông tin cảnh báo thiên tai về gió bão, lốc tố trên biển. Đặc biệt, nhu cầu dịch vu $\mathrm{y}$ tế trên biển rất cao, mang tính nhân đạo và hỗ trợ các hoạt động kinh tế và thực hiện các quyền chủ quyền và lợi ích quốc gia trên vịnh Bắc Bộ. Dịch vụ môi trường là một lĩnh vực kinh tế rất cần thiết khi phát triển kinh tế quy mô lớn gắn với bảo vệ môi trường trong thời kỳ hội nhập.

Kinh tế thủy sản (đánh bắt, nuôi trồng và dịch vụ hậu cần) và nông lâm nghiệp tại VCS không đưa lại giá trị GDP cao như dịch vụ và công nghiệp, nhưng mang lại lợi ích đáng kể cho nhiều người, đảm bảo lợi ích, công bằng xã hội và xóa giảm đói nghèo. Đẩy mạnh nghề cá biển ven bờ trên cơ sở đầu tư phát triển các cảng cá, các khu neo đậu tránh gió bão; hình thành các căn cứ hậu cần nghề cá lớn trong khu vực, đáp ứng yêu cầu phát triển khai thác xa bờ, kết hợp với bảo vệ an ninh quốc phòng trên biển; tập trung phát triển mạnh nuôi trồng thuỷ sản biển kết hợp với tham quan du lịch và ưu tiên nuôi trồng các loại đặc sản có giá trị cao phục vụ du khách và xuất khẩu. Lâm nghiệp định hướng phát triển phục hồi rừng ngập mặn với các chức năng phòng hộ và sinh thái gắn với bảo vệ tự nhiên, hỗ trợ bền vững nghề cá và du lịch ven bờ.

VCSHP có tiềm năng lớn phát triển các khu kinh tế, trong đó có khu trọng điểm Đình Vũ Cát Hải diện tích 21.640 ha và hệ thống cảng biển với cảng cửa ngõ Lạch Huyện, sân bay Cát $\mathrm{Bi}$, gần các khu du lịch Đồ Sơn, Cát Bà, có không gian rộng để bố trí các công trình và thiết kế kiến trúc đẹp ... Tuy nhiên, cần thận trọng khi phát triển các khu công nghiệp nặng, 
hóa chất và hóa dầu vì nhạy cảm về môi trường. Các ngành, lĩnh vực ưu tiên là công nghiệp cảng và các ngành công nghiệp, dịch vụ gắn với cảng; thương mại và ngân hàng, du lịch và vui chơi giải trí, xuất nhập khẩu, viễn thông, cứu hộ trên biển, dịch vụ xử lý ô nhiễm môi trường, các khu đô thị và cơ sở hạ tầng cho các khu dịch vụ công cộng hiện đại ...

\section{GIÁ TRI TÀI NGUYÊN ĐỊA - CHÍNH TRI}

\section{Phát triển không gian sinh cư và đô thị hóa} ven biển

Trên bờ VBB có 10 tỉnh thành thuộc Việt Nam từ Quảng Ninh đến Quảng Trị (theo ranh giới tự nhiên, còn có Thừa Thiên Huế) và 3 tỉnh Hải Nam, Quảng Đông và Quảng Tây thuộc Trung Quốc. Ở phía bờ Tây VBB, Việt Nam có 9 tỉnh và 1 thành phố trực thuộc trung ương, với tổng số 7 thành phố (01 loại I; 06 loại II), 4 quận, 2 thị xã và 35 huyện (5 huyện đảo). Dân sô 16,50 triệu người (Hải Phòng 1,84 triệu người), chiếm 19,2\% dân số cả nước. Trong đó, các huyện và quận ven biển có 6.747.747 dân, chiếm 7,8\% dân số cả nước [5]. VCSHP có vai trò quan trọng đối với định cư và phát triển các khu dân cư ven biển, mà ngày nay, cùng với sự phát triển về kinh tế, nhu cầu phát triển đô thị ven biển như là một quan hệ tất yếu.

Góp phần đảm bảo an ninh quốc phòng, hỗ trợ giữ vững chủ quyền và lọ̣i ích quốc gia trền biển

VCSHP có vai trò trọng yếu về vị thế chính trị vì có ý nghĩa đặc biệt quan trọng đối với đảm bảo an ninh quốc phòng, chủ quyền, lợi ích quốc gia trên biển và tạo lập mối quan hệ đặc biệt giữa Hải Phòng với Hà Nội, đầu não chính trị của đất nước, chỉ cách khoảng $100 \mathrm{~km}$.

Dòng sông Bạch Đằng lừng danh trong lịch sử, nơi người Việt đã ba lần lợi dụng địa hình, thuỷ triều để bày trận và đại thắng quân xâm lược Nam Hán, Tống và Nguyên Mông vào khoảng thế kỷ X-XIII. VCS Bạch Đằng là nơi khởi hấn của thực dân Pháp ở miền Bắc, dẫn đến xung đột ngày 20/11/1946 tại Hải Phòng, mở đầu cho Toàn quốc kháng chiến theo lời kêu gọi của Hồ chủ tịch ngày 19/12/1946. Phà Rừng và Bến Nghiêng (Đồ Sơn) là những tên lính xâm lược Pháp cuối cùng rút khỏi miền
Bắc (1955) theo Hiệp định Giơ-ne-vơ (1954). Trong những năm chống Đế quốc Mỹ, VCS Bạch Đằng vừa là cảng biển trọng yếu tiếp nhận hàng hóa và vũ khí, vừa là một căn cứ hải quân lớn bảo vệ vùng biển và vùng trời. Vì vậy, Mỹ đã phong tỏa ác liệt bằng thủy lôi, chiến hạm và không kích dữ dội vùng này. Đồ Sơn với bến tầu không số, là nơi khởi đầu của đường Hồ Chí Minh trên biển.

VCSHP còn có vị thế chính trị vô cùng quan trọng hỗ trợ giữ vững chủ quyền và lợi ích quốc gia trên $\mathrm{VBB}$ với vai trò là căn cứ xuất phát cho các hoạt động tuần tra, cứu nạn và cứu hộ, đánh bắt thủy sản, kiểm soát môi trường và nhiều hoạt động kinh tế khác trên biển.

\section{Giá trị về văn hoá bản địa}

VCSHP là cái nôi phát triển và lưu tồn nhiều giá trị văn hóa bản địa. Vùng có chiều sâu về lịch sử và văn hoá, gắn với những nhóm cư dân từ hậu kỳ đá cũ, những nhóm người Việt cổ cho đến các cộng đồng cư dân kinh tế mới trên các vùng đất khai hoang lấn biển. Đây là đất địa linh, nhân kiệt, có truyền thống lịch sử lâu đời dựng nước và giữ nước, truyền thống văn vật và thượng võ với nhiều danh nhân và khoa bảng.

Vì vậy vùng có nhiều lễ hội, rất phong phú và đặc sắc gắn với cuộc sống và gắn với biển của cư dân: Lễ hội Đền Dấu vào mùa xuân để cầu nguyện thần biển; Lễ hội Chọi trâu vào ngày 9 tháng 8 âm lịch tại Đồ Sơn thể hiện tinh thân thượng võ của người dân miền biển; Hội hát đúm ở Thuỷ Nguyên trước đây là một hình thức hát đối với làn điệu và phong cách sinh hoạt văn hoá ca hát rất đặc thù của địa phương vùng cửa sông ...

VCSHP và lân cận có nhiều di tích khảo cổ học nổi tiếng như di chỉ Tràng Kênh thuộc văn hoá Phùng Nguyên niên đại 3-4 nghìn năm trước; các di chỉ mộ thuyền thời Đông Sơn ở Bắc Thuỷ Nguyên có niên đại trên 2.000 năm. Quận Hồng Bàng tiền thân là làng Gia Viên cổ, từ hai nghìn năm trước đã gắn với quá trình khai phá VCS của nữ tướng Lê Chân. Đồ Sơn có di tích Phật giáo nổi tiếng là tháp Tường Long từ thời nhà Lý trên đồi Ngọc Sơn. VCS có nhiều di tích văn hóa và lich sử lịch sử gắn với các trận thủy chiến nổi tiếng trên sông Bạch Đằng năm 938 của $\mathrm{Ngô}$ Quyền và 1288 của 
Trần Hưng Đạo. Nhiều di tích văn hóa nổi tiếng phân bố trong không gian của VCS như hệ thống các đình làng, đền và chùa ven biển.

\section{KẾT LUẬN}

Vùng cửa sông ở Hải Phòng có giá trị lớn về tài nguyên vị thế với cả ba hợp phần địa-tự nhiên, địa-kinh tế và địa-chính trị, mang lại tiềm năng to lớn đối với phát triển kinh tế - xã hội. Đây là một trong những yếu tố cơ bản mang lại sự phồn thịnh của đô thị Hải Phòng, gắn với cảng biển ở cửa sông trong hơn một thế kỷ qua.

Theo quy hoạch phát triển kinh tế - xã hội của Hải Phòng và của vùng duyên hải Bắc $\mathrm{B}$ ộ, giá trị tài nguyên vị thế của VCS Bạch Đằng là một trong những yếu tố quan trọng bậc nhất hình thành nên khu trung tâm của vùng. Tại khu trung tâm - VCS Bạch Đằng, sự phát triển cần có sự liên kết và hỗ trợ giữa khu tả ngạn và khu hữu ngạn. Nếu phát triển thiên lệch về một phía là lãng phí to lớn tài nguyên vị thế của VCS này.

\section{TÀI LIÊU THAM KHẢO}

1. Lê Đức An, Trần Đức Thanh, 2010. Về vị trí địa lý và vị thế thành Thăng Long. Kỷ yếu Hội nghị Quốc tế: Phát triển bền vững Thủ đô Hà Nội văn hiến, anh hùng, vì hoà bình. Hà Nôii 7-9/10/2010. Nxb. ĐHQG Hà Nội. Tr. 969-980.

2. Lê Đức An, Uông Đình Khanh, Trần Đức Thạnh, Võ Thịnh, 2011. Tài nguyên vị thế hệ thống cửa sông Việt Nam. Tài nguyên và Môi trường biển. XVI: 20-28. Nxb. KHTN\&CN. Hà Nội.

3. Lê Đức An, Uông Đình Khanh, 2012. Địa mạo Việt Nam: cấu trúc - tài nguyên - môi trường. Nxb. KHTN\&CN. Hà Nội. 659 tr.

4. Nguyễn Cẩn, Nguyễn Đình Hòe, Trần Đức Thạnh, Nguyễn Đức Cư, Nguyễn Hũu Cư, Nguyễn Chu Hồi, 1994. Hoạt động đứt gãy hiện đại vùng Hải Phòng - Quảng Yên. Tài nguyên và Môi trường biển. II:54-60. Nxb. KH\&KT. Hà Nội.

5. Cục Thống kê tỉnh các tỉnh phía Bắc (tùr Quảng Ninh đến Quảng Bình), 2008. Niên giám Thống kê các tỉnh năm 2007. Nxb. Thống kê. Hà Nội.
6. Truơng Quang Hoc, 2012. Việt Nam-Thiên nhiên, môi trường phát triển bền vững. Nxb. KH\&KT. Hà Nội. 484 tr.

7. Nguyễn Chu Hồi, 2005. Cơ sở Tài nguyên và Môi trường biển. Nxb. ĐH Quốc gia Hà Nội. 306 tr.

8. Nguyễn Viết Phổ, Vũ Anh Tuấn, Trần Thanh Xuân, 2003. Tài nguyên nước Việt Nam. Nxb. Nông nghiệp. Hà Nội.

9. Pritchard, D.W., 1967. What is an Estuary? Estuaries Pub. No. 83. AAAS. Washington D.C, p. 149-157.

10. Trần Đức Thạnh, 1989. Điều kiện tự nhiên quận Hồng Bàng. Trong: "Địa chí quận Hồng Bàng". Nxb. Hải Phòng. 168 tr.

11. Trần Đức Thanh, 1991. Đặc điểm các bồn tích tụ hiện đại tiêu biểu ở dải ven bờ tây vịnh Bắc Bộ. Tài nguyên và Môi trường biển. I: 39-47. Nxb. KH\&KT. Hà Nội.

12. Trần Đức Thanh, 1999. Địa tầng Holocen và cấu trúc bãi triều ven bờ Hải Phòng. Các khoa học về Trái đất. 21 (3): 197-206.

13. Trần Đức Thạnh, Nguyễn Cẩn, Đặng Đức $N g a, 2000$. Bản chất cấu trúc estuary của vùng cửa sông Bạch Đằng. Tài nguyên và Môi trường biển. VII:35-50. Nxb. KH\&KT.

14. Trần Đức Thạnh, Nguyễn Cẩn, Đặng Đức Nga, Đinh Vắn Huy, 2004. Đặc điểm phát triển bờ và dao động mực nước biển Holocen ở khu vực Hải Phòng. Khoa học và Công nghệ biển. 4(3): 25-42.

15. Trần Đức Thạnh, 2007. Một số dạng tài nguyên vị thế biển Việt Nam. Khoa học và Công nghệ biển. Hà Nội. 7(4): 80-93.

16. Trần Đức Thạnh, Nguyễn Hũu Củ, Đinh Văn Huy, Bùi Văn Vượng, 2007. Các thuỷ vực ven bờ biển Việt Nam. Khoa học và Công nghệ biển. 7(1): 64-79.

17. Trần Đức Thạnh, 2008. Tác động của sóng, bão đối với các công trình bờ biển Bắc Bộ và giải pháp phòng tránh. Các Khoa học về Trái đất. 30(4): 555-565.

18. Trần Đức Thạnh, Đinh Văn Huy, 2008. Tiềm năng tài nguyên vị thế vùng cửa sông Bạch Đằng. Tuyển tập HNKH Địa lý toàn quốc lần thứ 3. Hà Nội, 16/12/2008. Nxb. KH\&KT. Tr. 367-376. 
19. Trần Đức Thạh, Trần Đình Lân, Nguyễn Hũu Cư, 2008. Tài nguyên vị thế biển Việt Nam, định dạng, tiềm năng và định hướng phát huy giá trị. Tuyển tập Hội thảo Quốc tế Việt Nam học lần thứ ba: "Việt Nam: Hội nhập và Phát triển". Hà Nội, 4 7/12/2008.

20. Trần Đức Thạh, 2009. Tiềm năng sử dụng các khu neo trú tránh bão, gió mạnh cho tàu thuyền trên vùng biển và ven bờ Việt Nam. Các khoa học về Trái đất. 31(2): 158-167.

21. Trần Đức Thạnh, Trần Đình Lân, Nguyễn Hũu Cử, Lăng Văn Kẻn, Nguyễn Văn Quân, Đinh Văn Huy, 2009. Một số vấn đề về phương pháp luận điều tra, đánh giá tài nguyên vị thế, kì quan sinh thái, địa chất vùng biển, ven bờ các đảo Việt Nam. Tài nguyên và Môi trường biển. XIV:1-14. Nxb. KHTN\&CN. Hà Nội.

22. Trần Đức Thạn, Đinh Văn Huy, 2010. Tài nguyên biển và ven bờ Hải Phòng: tiềm năng và triển vọng. Tài nguyên và Môi trường biển. XV: 5-20. Nxb. KHTN\&CN. Hà Nội.

23. Trần Đức Thạnh, Nguyễn Hũu Củ, Trần Đình Lân, 2010. Nhận thức cơ bản về tài nguyên vị thế biển Việt Nam. Tuyển tập Hội nghị Khoa học kỷ niệm 35 năm Viện KH\&CN Việt Nam. Tiểu ban KH\&CN biển. Nxb. KHTN\&CN. Hà Nội. Tr. 134140.

24. Trần Đức Thạnh, Nguyễn Hũu Củ, Đỗ Công Thung, Trần Đình Lân, Đinh Văn Huy, Pham Hoàng Hải, 2011. Định hướng quản lý tổng hợp vùng bờ biển Bắc Bộ. Nxb. KHTN\&CN. Hà Nội. 250 tr.
25. Trần Đức Thạnh, Lê Đúc An, 2012. Tài nguyên vị thế tự nhiên đảo Bạch Long Vĩ. Các Khoa học về trái đất. 34(4): 477-485.

26. Trần Đức Thanh, Nguyễn Hũu Cứ, Đinh Văn Huy, 2012. Định hướng quy hoạch không gian biển phục vụ phát triển kinh tế xã hội thành phố Hải Phòng. Tài nguyên và Môi trường biển. XVII: 5-14. Nxb. KHTN\&CN. Hà Nội.

27. Trần Đức Thạnh, Lê Đức An, Nguyễn Hũu Củ, Trần Đình Lân, Nguyễn Văn Quân, Tạ Hoà Phuoong, 2012. Biển đảo Việt Nam Tài nguyên vị thế và những kỳ quan địa chất, sinh thái tiêu biểu. Nxb. KHTN\&CN. Hà Nội. 324 tr.

28. Trần Đức Thạh, 2013. Đặc trưng cơ bản về điều kiện tự nhiên vùng chiến trường Bạch Đằng năm 1288. Kỷ yếu Hội thảo khoa học 725 năm Chiến thắng Bạch Đằng. Quảng Yên, 27/3/2013. Tr. 14-31.

29. Trần Đức Thanh, Lê Đúcc An, 2013. Tài nguyên địa - kinh tế và địa - chính trị đảo Bạch Long Vĩ. Khoa học và công nghệ biển. 13(3): 207-215.

30. Nguyễn Ngoc Thuy, 1984. Thủy triều biển Việt Nam. Nxb. KH\&KT. Hà Nội. 263 tr.

31. Trần Văn Trị (chủ biên) và nnk, 2012. Địa chất và tài nguyên Việt Nam. Nxb. KHTN\&CN. Hà Nội. 589 tr.

32. Xamoilov, I. B., 1952. Các vùng cửa sông. Nxb."Geographyz", Mascơva. Tr.1-526 (tiếng Nga).

33. Viện Nghiên cưu Trung Quốc, 2007. Khu kinh tế Vịnh Bắc Bộ (Quảng Tây). Tạp chí Nghiên cứu Trung Quốc. 5: 82-85. 


\title{
ESTUARINE AREAS IN HAI PHONG CITY - POSITION RESOURCES AND POTENTIAL FOR DEVELOPMENT
}

\author{
Tran Duc Thanh ${ }^{1}$, Le Duc An ${ }^{2}$, Trinh Minh Trang ${ }^{1}$ \\ ${ }^{1}$ Institute of Marine Environment and Resources -VAST \\ ${ }^{2}$ Institute of Geography-VAST
}

\begin{abstract}
The estuarine areas (EAs) in Hai Phong have great potential for the socieconomic development of this city. Regarding the geo-natural resources, EAs are the focal location of the waterway systems; transition zone between mainland and sea; hinge between the Northeast coastal zones and Red River Delta; and the gateway to Northern Vietnam from South China. They are classic delta and estuary having, semi-closed structure, with stably large and deep river mouths, and extensive intertidal zones. EAs have the long lasting natural evolution and locate in the coastal tropical monsoon zone, where the natural conditions are rather stable and the natural disasters are not too harsh. This is also the region with other natural resource abundance; and especially the regimes of diurnal tide in large range typically bring huge benefits of economy and environment. With respect to the geo - economic resources, EAs are valuable sea wand gate in coastal Northern Vietnam and have the role in linking Hai Phong city with capital Ha Noi. These are the central area of the economic space in coastal zone of Northern Vietnam and are the centre of the economics system with two corridors (Hai Phong - Ha Noi - Nanning and Hai Phong - Ha Noi - Kunming)one economic belt (Gulf of Tonkin) in the development process of international integration. In particular, they are favorable localities to prioritize development of marine economic sectors and key marine economic zone. Concerning the geo - politic resources, EAs are the development space of residential areas and coastal urbanization, the convergence of many factors that contribute to ensuring national security, support for national sovereignty and interests on the sea. This is also the place where the values of unique indigenous culture are developed and preserved.
\end{abstract}

Keywords: Position resources, estuarine areas, Hai Phong. 